\title{
Georgia: Higher Education System Dynamics and Institutional Diversity
}

\author{
Lela Chakhaia and Tamar Bregvadze
}

\section{Higher Education in Georgia at the Time OF INDEPENDENCE}

As one of the three South Caucasian post-Soviet republics, Georgia is located on the eastern coast of the Black Sea. Over 80 per cent of its 3.7 million inhabitants are ethnic Georgians. Other large ethnic and language groups residing in the country include Armenians, Russians, Azeris, Abkhazs and Ossetians. Even though the country has made significant strides towards improving the economic and social conditions of its citizens during the last decade, a large proportion of the population is still under the poverty threshold and economic inequality is substantial. With the officially declared state goal of joining the European Union and NATO, the Georgian government and the people of Georgia see themselves as an indispensable part of the Western world.

L. Chakhaia $(\bowtie)$

European University Institute, Florence, Italy

T. Bregvadze

Ilia State University, Tbilisi, Georgia

(C) The Author(s) 2018

175

J. Huisman et al. (eds.), 25 Years of Transformations of Higher

Education Systems in Post-Soviet Countries, Palgrave Studies in Global

Higher Education, https://doi.org/10.1007/978-3-319-52980-6_7 
Just before Georgia gained independence, higher education was part of the Soviet system and was accordingly standardised in terms of both form and substance. The higher education institutional landscape was very similar to those in the other Soviet republics (Sharvashidze 2005). All higher education institutions (HEIs) were exclusively owned by the state and the full course of studies was subsidised by the state; this was to achieve the ideal of total equality for all. In terms of disciplinary diversity, HEIs were often highly specialised and roughly divided into the following categories: comprehensive universities preparing professionals for a wide range of disciplines; specialised HEIs, which were institutes preparing professionals for specific professions (in most cases technical, medical and agricultural); pedagogical institutes established in regional centres with the dual purpose of preparing teachers and providing access at regional level; and institutes of art and culture. The number of HEIs in the country remained more or less constant throughout the entire history of the Soviet Union. Until the beginning of the 1990s there was only one HEI which bore the title of university and provided comprehensive education. This was the oldest and most well-known institution in the country, Tbilisi State University.

However, the number of students grew both nominally and as a share of the respective age group. In line with the Soviet trend of higher education massification that started at the end of the 1960s (Matthews 1972), this development was reflected in Georgia as well. As seen from Fig. 7.1, absolute enrolments as well as enrolments per 10,000 people doubled

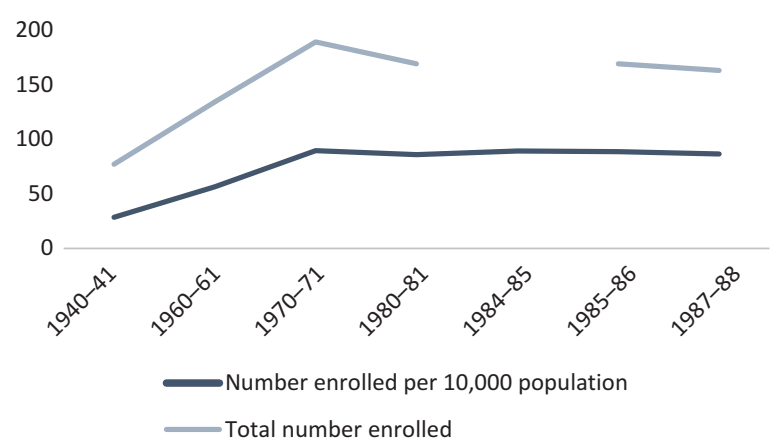

Fig. 7.1 Number of HEIs and enrolments in Soviet Georgia (Source: Savelyev et al. 1990) 
from the beginning of the 1940s to the beginning of the 1960s, although the number of institutions remained stable.

Since the start of the 1970s, the number of enrolled students remained flat and by 1988 there were 19 higher education institutions (HEIs) enrolling some 86,400 students with more than 100 specialisations and 4 to 16 faculties at each university. With a gross tertiary enrolment ratio of 30 per cent, Georgia had one of the highest participation rates in the Soviet countries by the time it gained independence.

As mentioned above, the main distinction between HEIs during the Soviet period was in terms of fields of study, with some offering a comprehensive range of programmes (universities) and some confined to educating professionals for specific fields (institutes). Another important classification factor was the location of universities: to expand access to higher education geographically, the Soviet government encouraged the opening of institutes in various regions. In terms of study structure, all HEIs offered single-cycle programmes, which typically lasted for five years, and issued 'specialist' diplomas upon graduation. An exception to this rule were medical institutes, which provided longer courses of study although the degree conferred was the same. There was therefore no distinction between HEIs regarding the level of qualifications awarded. Another point of distinction was the possibility to receive a graduate research degree. It was possible to pursue graduate degrees at universities and at some institutes as well. There was no formal way of distinguishing quality differences between HEIs in Soviet Georgia, since there were no formal rankings in place. However, there was an informal understanding of which HEIs were 'prestigious' and because HEIs were in most cases highly specialised, the prestige of a particular HEI or programme was often equated with the prestige of the discipline.

To sum up, the higher education institutional landscape in Georgia in the final years of the Soviet Union just before independence can be described as follows (Table 7.1).

\section{Framework for Classification of Higher Education Institutional LANDSCAPE In GEORGIA}

The transformation of Georgian higher education started immediately after the country gained independence. The changes that took place throughout the subsequent 25 years varied in scope, structure, agency and impact. There are several major dimensions along which the system developed and 
Table 7.1 Classification of Georgian HEIs by the end of the 1980s

\begin{tabular}{|c|c|c|}
\hline Type of HEI & Description & HEIs \\
\hline University & $\begin{array}{l}\text { HEI offering extensive range of disciplines; } \\
\text { under the supervision of the Ministry of } \\
\text { Education; opportunity for postgraduate } \\
\text { study and research; varying prestige } \\
\text { depending on the field of study }\end{array}$ & $\begin{array}{l}\text { Tbilisi State University } \\
\text { (the only university in } \\
\text { Soviet Georgia) }\end{array}$ \\
\hline $\begin{array}{l}\text { Specialised } \\
\text { professional } \\
\text { institutes }\end{array}$ & $\begin{array}{l}\text { HEI offering programmes in specific fields } \\
\text { of study and preparing professionals to work } \\
\text { in certain areas; under the supervision of } \\
\text { various ministries; opportunity for } \\
\text { postgraduate study and research; varying } \\
\text { prestige depending on the institute and the } \\
\text { field of study; located in Tbilisi }\end{array}$ & $\begin{array}{l}\text { Technical Institute of } \\
\text { Georgia } \\
\text { Medical Institute of } \\
\text { Georgia } \\
\text { Agrarian Institute of } \\
\text { Georgia } \\
\text { Foreign Languages } \\
\text { Institute of Georgia }\end{array}$ \\
\hline $\begin{array}{l}\text { Culture and arts } \\
\text { institutes }\end{array}$ & $\begin{array}{l}\text { HEI offering programmes and preparing } \\
\text { professionals in various domains of arts and } \\
\text { culture; under the supervision of various } \\
\text { ministries; usually highly prestigious; located } \\
\text { in Tbilisi }\end{array}$ & $\begin{array}{l}\text { State Academy of Arts } \\
\text { Tbilisi State } \\
\text { Conservatory } \\
\text { State Institute of } \\
\text { Theatre and Film }\end{array}$ \\
\hline $\begin{array}{l}\text { Pedagogical } \\
\text { institutes }\end{array}$ & $\begin{array}{l}\text { HEI preparing school teachers in various } \\
\text { subject disciplines; varying prestige } \\
\text { depending on the institute and the field of } \\
\text { study but usually less prestigious compared } \\
\text { to most other HEIs; located in regions, one } \\
\text { in Tbilisi }\end{array}$ & $\begin{array}{l}\text { Tbilisi Pushkin } \\
\text { Pedagogical Institute } \\
\text { Kutaisi Pedagogical } \\
\text { Institute } \\
\text { Batumi Pedagogical } \\
\text { Institute } \\
\text { Sokhumi Pedagogical } \\
\text { Institute } \\
\text { Tskhinvali Pedagogical } \\
\text { Institute } \\
\text { Gori Pedagogical } \\
\text { Institute }\end{array}$ \\
\hline
\end{tabular}

which are still shaping its current institutional landscape. In fact, these developments are reflected very accurately in the institutional setup of higher education.

Firstly, a distinction should be made between HEIs by form of ownership, meaning whether they are publicly or privately owned. Privatisation of higher education was perhaps the first major significant transformation of the system, resulting directly from the rapid transition from a centralised state-run economy to a market economy. The next distinction is horizontal substantial differentiation distinguishing between HEIs based on the 
variety of study fields offered. This dimension was influenced by the marketisation of the economy as well as by the changing demands of the labour market. The major trend in this regard has been diversification and broadening of narrow fields of specialisation. Further, there is horizontal structural differentiation between HEIs by degree of education offered and level of research and education integration. This is a more recent development that is closely tied with joining the Bologna Process and the related changes in the system. It is also important to highlight vertical differentiation by quality. This is more complicated in terms of suitable measurements, but we propose certain proxies.

Further distinctions can be made between HEIs by location: the capital city of Tbilisi is not only the biggest city in the country by more than eight times the population of the next biggest city (Kutaisi), but its economy is also far ahead of any other city or region. Therefore, it is perhaps no surprise that most of the HEIs in the country, 75 per cent, are located in Tbilisi. Next, there are important distinctions between HEIs based on size, ranging from a few hundred to several thousand students.

\section{Overview of Socioeconomic and Political DEVELOPMENTS}

The development of higher education in post-Soviet Georgia mirrors the country's political and socioeconomic landscape and closely follows the timeline of major transformations. In Georgia, the economic and political hardships common to all post-Soviet countries were accompanied by a severe civil war in 1991-1992 and two violent ethnic conflicts in the autonomous regions of Abkhazia and South Ossetia. Nationalistic sentiments were on the rise and the country was in a state of chaos after the first democratically elected post-independence government was ousted by a military coup.

Together with Moldova, the Georgian economy suffered most with an average annual economic decline of 24 per cent between 1990 and 1994; the GDP in 1994 constituted only 28 per cent of its 1989 level (Mitra and Selowsky 2002). Total GDP composition, which in 1990 was roughly equally distributed between industry, agriculture and service sectors, was also radically asymmetric in 1994 with agriculture accounting for 65 per cent and industry a mere 10 per cent (World Bank 2009). These changes had crucial implications for labour market demands, and as a further consequence, for demands on formal education. 
Unemployment rates increased in parallel with the economic decline. In addition, the economic decline did not affect all groups evenly. As a result, income inequality as measured by the Gini coefficient increased dramatically, soaring from 26 in 1990 to 43 in 1993 (Mitra and Selowsky 2002).

The political crisis resulting from the overthrow of the first elected president continued for almost three years, but the situation began to change in 1994 when a new government was installed. Central and local government institutions and agencies were slowly being restored and started functioning again, even if not efficiently. The economy grew rapidly as national assets were privatised, and the political situation was relatively stable except for the aforementioned cases of Abkhazia and South Ossetia. Conflict in these areas was at a standstill, but tensions arose from time to time. Meanwhile, income inequality continued to grow. Political discourse was largely dominated by the need to maintain stability after years of conflict, upheaval and disorder. Perhaps the most prominent feature of the public sector during this period was inefficiency and rampant corruption at every level (Transparency International 2002).

Starting in 2004 after the so-called Rose Revolution, the Georgian government undertook a set of sweeping countrywide reforms aimed at combatting corruption and increasing the efficiency of public services. A team of liberally minded young economic reformers set out to radically transform the country and make it a post-Soviet success story. The economy grew steadily with the exception of 2008-2009, when growth was hindered by both the global financial crisis as well as war with Russia.

The economic policies of the new government, especially during the first years, were based on the principles of deregulation and liberalisation. After privatising national assets, the privatisation of public services ensued. These reforms, which were commended by international organisations (World Bank 2009; OECD 2011), indeed succeeded in eradicating corruption at lower levels by limiting bureaucracy and improving efficiency in all public sectors.

The educational system, higher education in particular, was not only part of the extensive reform package that the new government implemented after the Rose Revolution; it was also one of the most prominent and highly debated. It is therefore deemed appropriate to divide the review of the Georgian higher education system development into two parts: before and after the Rose Revolution. 


\section{Higher Education System Development: An Overview BEFORE 2005}

As explained earlier in this chapter, developments in the higher education system have closely reflected the political and socioeconomic changes in the country since independence in 1991. All the features characteristic of the public governance system in the independent republic of Georgia during its first years of existence, as outlined above, were also relevant for its higher education system. The system functioned largely through inertia, and hence a number of defining features from the Soviet education system were retained. However, lack of experience in the planning and management of education systems resulted in somewhat haphazard developments.

From the outset, economic hardships in the country were reflected in the funding of the education system. Together with the dramatic economic decline described above, the share of educational funding as a percentage of GDP also shrank from about 7 per cent in 1991 to a mere 1 per cent in 1994 (Perkins 1998; Sharvashidze 2002).

In terms of institutional development and structural arrangement, the higher education system maintained many of the basic features of the Soviet period; changes, if there were any, were slow. There was no topdown effort to reform the system and no effort on the part of HEIs themselves to initiate substantive changes. As in other public sectors, the system was occupied with adjusting to new realities rather than substantially reforming. Rapid privatisation of the sector and disciplinary diversification of previously narrowly specialised HEIs were clear signs: these were unregulated and unplanned transformations to respond to the demands of the market economy and the labour market.

\section{Privatisation and Ownership of HEIs}

Privatisation of higher education was one of the most significant developments in the Georgian higher education system in the 1990s. Private educational institutions were opened alongside state institutions on the basis of the Decree of the Supreme Council of the Republic of Georgia, which was issued in June 1991. Privatisation also occurred through the introduction of tuition fees ${ }^{1}$ at existing public HEIs, a change authorised by the government in 1993. 
Growth and expansion of private higher education institutions in Georgia was spectacular; some 200 licenses for private HEIs were issued by the Ministry of Education and Science in 1991-1992. However, many of these were very short-lived and closed down within a year or two as shown in Fig. 7.2 below. The number decreased to 93 by 1993, but in the following years many more private HEIs were established for a total of 172 by $2004-2005$. As Georgia had no history of managing a private higher education sector, there was no regulatory procedure in place for authorisation or accreditation of these newly established HEIs.

The structure, profile and status of the new HEIs were very diverse. Most of them were established as for-profit organisations by entrepreneurs who saw an opportunity to gain profit under the liberalised market system. There was a large segment of not-for-profit institutions as well, such as theological academies established by the Patriarchate of Georgia in various regions. Private HEIs received funding from tuition fees as well as endowments or other funds received from private sources such as gifts or donations, and funds received through agreements with the state and other legal entities. Tuition fees, however, constituted the largest part of their budgets (Sharvashidze 2005). No public institutional funding was available until major changes in the system in 2005 .

\section{0}

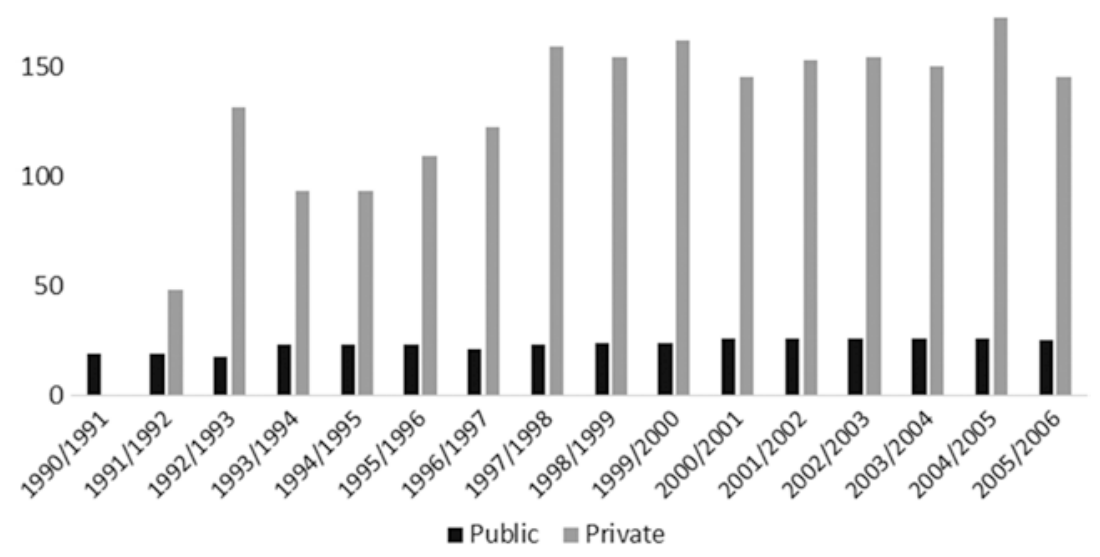

Fig. 7.2 Number of HEIs 
The regional distribution of newly emerging private HEIs was another important issue. By the time of independence, almost all HEIs except for pedagogical institutes were located in Tbilisi. In the 1990s, even though the majority of new private HEIs were still located in Tbilisi, about onethird were in the regions. Figure 7.2 illustrates that while the number of private HEIs increased remarkably throughout the 1990s (with a small drop in 1995), the number of public HEIs remained stable.

On the other hand, the number of students enrolled in private universities, presented in Fig. 7.3, was much lower compared to public universities. To be more precise, at an earlier stage students at private HEIs constituted almost one-third of the entire student body. However, student numbers later dropped at private institutions and grew at public HEIs. It should be noted that the numbers presented in Figs. 7.2 and 7.3 regarding private HEIs and student numbers are only indications and should be considered with reservation. There are discrepancies in the numbers provided by the National Department of Statistics and the Ministry of Education and Science, which could result in possible inaccuracies.

The reasons for such dynamics are complex. Firstly, most of the newly established private HEIs had limited capacities due to lack of appropriate human and material resources. Facilities were in dire shape and inappropriate

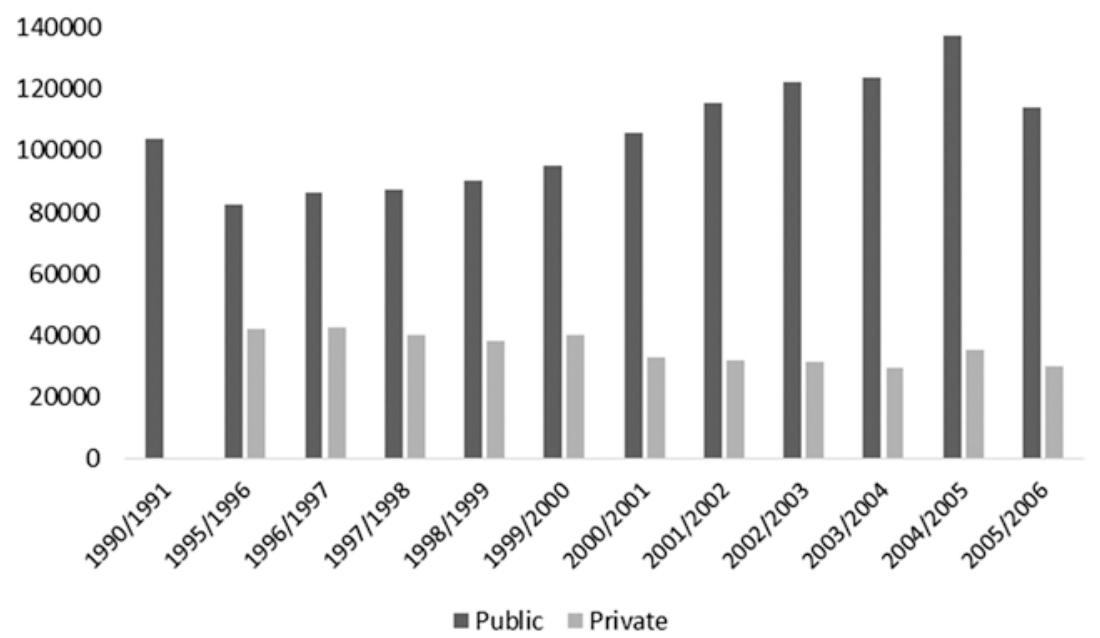

Fig. 7.3 Absolute student enrolments 
for full operation. According to some accounts, about 30 per cent of all private HEIs shared premises with secondary schools or other organisations (Sharvashidze 2005).

Expansion in enrolment rates at public universities came largely at the expense of students themselves in the form of tuition fees. While in 1994-1995 fee-paying students constituted only 10.7 per cent of total enrolment, in 1997-1998 this number went up to 48 per cent and was stable till 2005. The number of students in tuition-free tracks, on the other hand, remained more or less constant.

It is important to point out that tuition fees constituted a substantial portion of income for public HEIs. In some cases, revenues received from tuition fees were more than double in volume compared to the funding provided by the state (Gvishiani and Chapman 2002).

\section{Governance of Higher Education}

As it was no longer under Soviet control, the education system was regulated by the laws of independent Georgia and supervised by the Ministry of Education. Universities enjoyed relative freedom in terms of designing teaching programmes and curricula, and in establishing tuition fees. However, the number of students admitted was still negotiated with the government. Centralised control of public HEIs was absent or weak, but this was not so much an expression of institutional autonomy as it was a result of poor governing capacity at the central administrative level. In fact, lack of unified vision and coherent national policy was a defining feature of Georgian higher education development during the first transition phase, until 2003. Most changes were restricted to the institutional level without substantively reforming the system.

One of the most prominent features of the Georgian higher education system during the 1990s and early 2000s was rampant corruption. Higher education was no exception to the common trend, as it was a deeply rooted practice in each public sector and inhibited many attempts at progress and efficiency. As testified by a series of reports and academic research (Orkodashvili 2009; Lorentzen 2000), corruption practices were present in admission procedures as well as during the academic process through different channels, most notably in the form of bribery and nepotism. The admissions exams administered by each university were a source of substantial income for those involved in the admissions process, as people were willing to pay large amounts in bribes; up to 20,000 USD in some 
cases, depending on the prestige of the university and the field of study. Corruption during admissions was largely limited to the tuition-free tracks in public universities. Only a very small number of top performing applicants were able to access prestigious universities or fields without paying bribes (Lorentzen 2000).

In general, the admissions system remained the same as it was during the Soviet period. Applicants were required to pass university-level, subject-specific competitive examinations. Until 2000 there was no possibility to register for examinations at different universities, thus limiting applicant chances to enrol in higher education. Once enrolled, students also had very limited opportunities to transfer to a different HEI or even to a different field of study.

The study structure remained unchanged until the late 1990s. This meant that the course of study in all universities and all departments consisted of five years, after which a graduate received a specialist diploma in the particular field. Those who wanted to work towards an academic degree stayed in the university or moved to a research institution.

As early as 1996, universities began shifting towards an Anglo-Saxon education model with a two-tier system comprised of a four-year bachelor cycle and a two-year master cycle. This was an attempt to bring the system closer to the standards of the Bologna Process. However, for a very long time this formal change did not translate into a fundamental reorientation of the system. In the initial stages of system transformation, the previous single-track five-year study programme was simply split without adapting the contents (Lorentzen 2000). This did not change until almost ten years later when the country formally joined the Bologna Process.

\section{Rank and Prestige of Georgian HEIs}

The issue of increasing access to higher education is tied to the question of returns to education. As attainment rates grow, returns might remain the same, they might shrink, or they might be affected differently based on the type and prestige of the degree. The ranking of universities according to quality is a helpful tool for both applicants and their parents wishing to distinguish themselves, as well as for employees wishing to recruit candidates with the best skills. But, it is difficult to assess whether higher-ranking universities actually help students develop better skills, or whether they receive 'better' applications in the first place because they are highly selective. In this respect, the argument resembles the distinction between 
'human capital' and 'signalling' approaches to analysing returns to higher education.

In Soviet Georgia, as well as in the 1990s, there was an informal distinction between HEIs based on quality and prestige. It is hard to evaluate what exactly constituted the main reasons for HEI prestige during the Soviet period. However, since all HEIs except TSU were highly specialised, institutional prestige was strongly linked to the prestige of the discipline. For example, the Medical Institute was very prestigious as doctors enjoyed a high social status. The Institute of Foreign Languages was another popular HEI, albeit mostly for females. The Agrarian Institute and to a lesser extent the Polytechnic Institute, on the other hand, were considered less popular. Also within Tbilisi State University (TSU), certain disciplines were much more prestigious than others.

In the 1990s when all HEIs whether public or private introduced considerable disciplinary diversity, the situation changed and disciplinary competition was transformed into institutional competition. There were huge differences between the newly emerging private universities. As Pachuashvili (2009) describes, most small private HEIs served to simply absorb the demand for 'more education'. At the same time, by the end of the 1990s, a small group of more prestigious private HEIs had emerged. The success and prestige of these selected few private institutions was perhaps determined by the availability of extensive financial resources, and hence the possibility to attract better teaching staff for higher pay as well as offering better-equipped facilities. In many cases these prestigious private HEIs were co-funded by international foundations, donor organisations and large private companies. These HEIs were highly selective and completion rates were quite low due to demanding requirements. Employer appreciation of diplomas from this small set of private universities was therefore very high. This, in turn, cyclically contributed to the growth of their prestige. However, even these prestigious private HEIs were more focused on skills training and less on academic and research output (Gvishiani and Chapman 2002; Pachuashvili 2009). Table 7.2 shows completion rates as well as job placement rates for graduates from these prestigious private HEIs (at that time Georgian Institute of Public Affairs, GIPA, had a very high completion rate because it initially offered only MA level courses).

Tuition-free tracks in certain disciplines at some public HEIs enjoyed the same high social ranking as the prestigious private universities listed above. These public HEIs were also popular during the Soviet period. 
Table 7.2 Performances of private HEIs

\begin{tabular}{|c|c|c|}
\hline HEIs & Graduation rate (\%) & Job placement (\%) \\
\hline Georgian Institute of Public Affairs (GIPA) & 97 & 91 \\
\hline European School of Business (ESM) ${ }^{\mathrm{a}}$ & 62 & 87 \\
\hline Caucasus School of Business (CSB $)^{b}$ & 89 & 77 \\
\hline International Black See University (IBSU) & 87 & 92 \\
\hline Alma Mater University ${ }^{c}$ & 90 & 86 \\
\hline
\end{tabular}

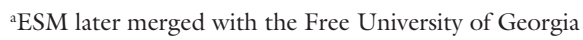

${ }^{\mathrm{b} C u r r e n t l y ~ a ~ C a u c a s u s ~ U n i v e r s i t y ~ S c h o o l ~}$

'Now Grigol Robakidze University

Source: Sharvashidze (2005)

\section{First-tier}

-Prestigious private HEIs (e.g. GIPA, ESM)

-Tuition-free tracks at some departments at prestugous universities (e.g. tuition-free track, Law department at TSU)

\section{Second-tier}

-Tuition-charging tracks of prestigious departments at 'good' public HEls

-All tuition-free departments at 'good' universities

\section{Third-tier}

-Tuition-charging departments at 'good' public HEls

- Other public HEls

\section{Fourth-tier}

-'Demand-absorbing' private HEls

Fig. 7.4 Classification of Georgian HEIs in the 1990s by prestige and rank

At public universities, prestige and rank were defined by two factors: field of study and tuition fee status. The latter was important because students were admitted to 'free' tracks solely on merit. Merit was measured by admissions examinations, which were administered by HEIs themselves and highly corrupt. Overall, selectivity at admission was arguably the most important factor defining university prestige. In terms of prestige, HEIs and programmes were roughly ranked as presented in Fig. 7.4. 


\section{Disciplinary Diversification of Georgian $\mathrm{HE}$}

As described above in the section on higher education in Soviet Georgia, HEIs were classified by field of study and were usually narrowly specialised. There was only one HEI with formal 'university' status, Tbilisi State University, which offered programmes in diverse disciplines ranging from humanities to hard sciences. All other HEIs were specialised in a narrow set of disciplines. The basic classification of these HEIs was into technical institutes, medical institutes, agrarian institutes, teacher training institutes and art institutes.

However, immediately after the break-up of the Soviet Union, the education system became independent from central control and this situation changed. In fact, lax regulations and the virtual absence of an appropriate legal framework gave public HEIs the freedom to transform courses of study, structure and even status. Most began to adjust the contents of their educational programmes to meet the emerging demands of young people. Already in the 1990s, law and business studies proved to be the most popular fields (Lorentzen 2000). As funding from the public budget was reduced, public HEIs offered a growing number of places in these disciplines as fee-paying tracks.

As all HEIs except TSU were previously institutes with narrow specialisations, most changed their status from institute to university in order to offer new trendy disciplines. For example, the Polytechnic Institute became the Technical University of Georgia and Tbilisi Medical Institute became Tbilisi Medical University. This was in principle merely a name change, especially since no formalised definition was in place (Sharvashidze 2005; Pachuashvili 2009).

Similarly, pedagogical institutes were transformed into universities and started to offer undergraduate and graduate programmes in a wider range of disciplines. Since most of these pedagogical institutes were located outside the capital city of Tbilisi, they effectively became regional universities. The expansion of higher education into the regions was further enhanced by the establishment of eight TSU branches in various cities throughout the country. As previously pointed out, HE sector development was not strategised or planned in detail at the national level. Institutional-level changes were initiated by HEIs themselves and negotiated with the government, often through personal connections and power networks. 


\section{Developments After 2005}

From 2004, the new government of Georgia that came into power after the Rose Revolution embarked on a comprehensive reform programme. As described earlier, reforms in public governance were aimed at fighting corruption, inefficiency and inflexibility. Underlying many of these reforms were the principles of the market economy and New Public Management. Guided by the drive toward marketisation and competitiveness and encouraged by an extremely positive response from the World Bank, the International Monetary Fund and other international agencies, many public institutions were fundamentally transformed in a seemingly very short period of time.

The changes that occurred in the higher education system in Georgia at the same time were no less dramatic. The system was entirely revamped by interwoven sets of reforms. Most notable were changes in higher education funding, admission mechanisms and quality control. All the changes were closely connected and took place simultaneously. Effective as the changes were in improving efficiency and eliminating corruption, they were truly top-down reforms; they were therefore part of larger reform efforts not driven by the HEI community.

Table 7.3 presents the typology of present-day HEIs in Georgia. The following sections will describe the processes that have shaped it during the last decade.

\section{Accreditation and Quality Assurance}

The development of external and internal higher education quality assurance systems started after the adoption of a new Law of Georgia on Higher Education in 2004 and coincided with joining the Bologna Process in 2005. In addition to making the three-tier HE system compatible with international systems, the enactment of the Bologna Process ensured that $\mathrm{HE}$ and scientific research would be brought closer together (Bakradze 2013).

The process of institutional accreditation was initiated in 2004 by the semi-autonomous National Accreditation Centre (later the National Quality Enhancement Agency) under the Ministry of Education and Science. The institutional accreditation procedure involved HEI compliance with certain requirements concerning their institutional capacity and physical facilities. As a result, the number of HEIs was dramatically 
Table 7.3 Current typology of Georgian HEIs

\begin{tabular}{|c|c|c|c|c|}
\hline Type of HEI & Research & Prestige & $\begin{array}{l}\text { Disciplinary } \\
\text { diversity }\end{array}$ & HEIs in this category \\
\hline $\begin{array}{l}\text { Leading public } \\
\text { comprehensive } \\
\text { universities }\end{array}$ & Integrated & High & Wide & $\begin{array}{l}\text { TSU, Ilia State } \\
\text { University }\end{array}$ \\
\hline $\begin{array}{l}\text { Leading private } \\
\text { comprehensive } \\
\text { universities }\end{array}$ & Integrated & High & $\begin{array}{l}\text { Medium to } \\
\text { wide }\end{array}$ & $\begin{array}{l}\text { Free University, Black } \\
\text { Sea International } \\
\text { University, Caucasian } \\
\text { University, GIPA, } \\
\text { Georgian-American } \\
\text { University }\end{array}$ \\
\hline $\begin{array}{l}\text { Specialised } \\
\text { universities }\end{array}$ & Integrated & $\begin{array}{l}\text { Medium } \\
\text { to high }\end{array}$ & $\begin{array}{l}\text { Narrow to } \\
\text { medium }\end{array}$ & $\begin{array}{l}\text { Tbilisi State Medical } \\
\text { University, Agrarian } \\
\text { University, Tvildiani } \\
\text { Medical University, } \\
\text { Academy of Arts, } \\
\text { Theatre and Film } \\
\text { University, } \\
\text { Conservatory, } \\
\text { Georgian Aviation } \\
\text { University }\end{array}$ \\
\hline $\begin{array}{l}\text { Comprehensive } \\
\text { universities }\end{array}$ & Integrated & Medium & $\begin{array}{l}\text { Medium to } \\
\text { wide }\end{array}$ & $\begin{array}{l}\text { Georgian Technical } \\
\text { University, University } \\
\text { of Georgia, Robakidze } \\
\text { University, Davit } \\
\text { Aghmashenebeli } \\
\text { University of Georgia, } \\
\text { Saint Andria } \\
\text { University }\end{array}$ \\
\hline $\begin{array}{l}\text { Highly specialised } \\
\text { public teaching } \\
\text { universities }\end{array}$ & $\begin{array}{l}\text { Partly } \\
\text { integrated }\end{array}$ & Medium & Narrow & $\begin{array}{l}\text { Ministry of Internal } \\
\text { Affairs Academy, } \\
\text { Defence Academy }\end{array}$ \\
\hline $\begin{array}{l}\text { Regional } \\
\text { comprehensive } \\
\text { universities }\end{array}$ & Integrated & Medium & $\begin{array}{l}\text { Medium to } \\
\text { wide }\end{array}$ & $\begin{array}{l}\text { Batumi State } \\
\text { University, } \\
\text { Gogebashvili } \\
\text { University, Samtskhe- } \\
\text { Javakheti University, } \\
\text { Kutaisi State } \\
\text { University, Sokhumi } \\
\text { State University }\end{array}$ \\
\hline Teaching universities & $\begin{array}{l}\text { Partly } \\
\text { integrated }\end{array}$ & Low & $\begin{array}{l}\text { Medium to } \\
\text { wide }\end{array}$ & $\begin{array}{l}\text { All other teaching } \\
\text { universities }\end{array}$ \\
\hline Colleges & $\begin{array}{l}\text { Not } \\
\text { integrated }\end{array}$ & Low & Medium & All colleges \\
\hline
\end{tabular}


reduced. As shown in Fig. 7.5, so was the number of newly enrolled students, as the state imposed a cap on public university admission; this cap was among the accreditation requirements.

In 2010, the system was modified and since then universities have been required to obtain mandatory authorisation to operate as institutions. In addition, they can apply for the accreditation of individual programmes in order to be eligible for public funding to support students enrolled in those programmes. Although programme accreditation is not compulsory, HEIs are interested in this option because programmes with public funding are expected to attract more students.

Figure 7.5 also shows that the number of universities and enrolments has bounced back somewhat. This is because when the accreditation procedures were initially introduced in 2005, many HEIs were not ready to meet the new requirements; they have since adjusted their practices over time. Additionally, it can be argued that authorisation procedures are milder than those for institutional accreditation (Darchia 2013).

As described above, joining the Bologna Process in 2005 was a step towards transforming the higher education system into a three-cycle structure that would be easily recognised and comparable at the international level. By introducing research projects into the first and second cycles of higher education as well as introducing doctoral education, the Law of

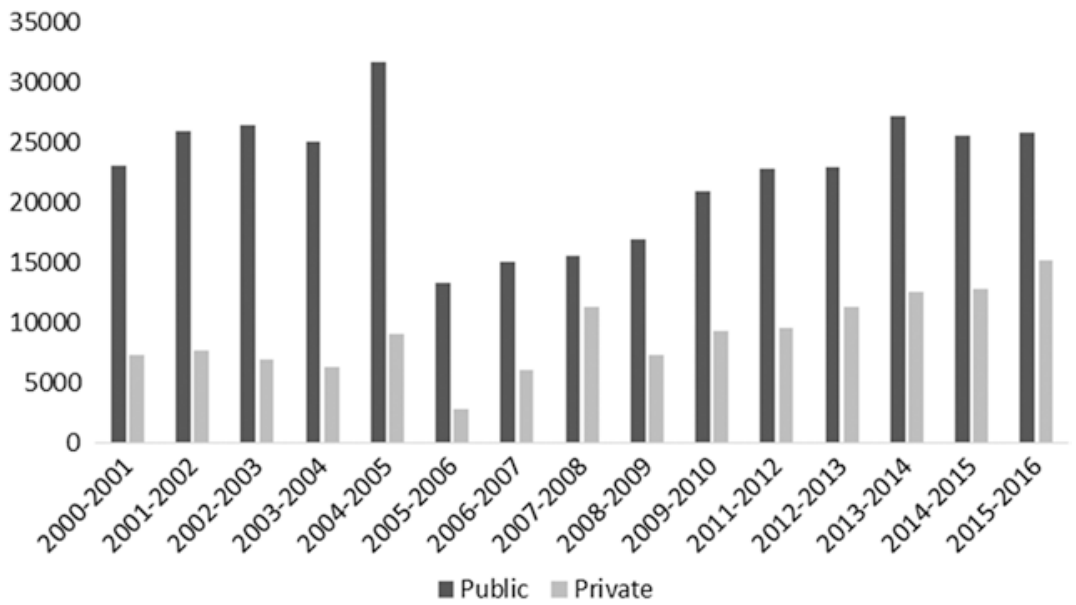

Fig. 7.5 Number of admitted students in HEIs 
Georgia on Higher Education created a legal basis for integration of the higher education and science systems. $\mathrm{PhD}$ studies became an important element by integrating higher education and research.

As a result, all HEIs in Georgia are currently divided into groups by level of education and the degree of research and teaching integration. Universities offer bachelor, master and doctoral programmes; teaching universities offer master and bachelor programmes; and colleges offer only bachelor-level programmes. Accordingly, universities combine research and teaching, while teaching universities and colleges are solely focused on teaching. Such classification presents a remarkable break from the Soviet tradition, which considered HEIs primarily as places for teaching while most research was conducted at the Academy of Sciences.

\section{Admissions Exams}

Introducing centralised standardised examinations-Unified National Examinations (UNEs) - in 2005 was the single most important measure implemented by the government to fight corruption during the admissions process. Another major goal of introducing UNEs was to improve access for disadvantaged but talented students, as admission would be meritocratic. It was believed that the previous system disproportionately favoured those coming from families with ample financial resources and social capital. UNEs replaced exams previously administered by individual universities and became the sole admissions criterion (with minor exceptions, discussed below). The exams are administered in Georgian or English and focus on the relevant subject discipline (based on the study area selected by the applicant) and general aptitudes (verbal and mathematic). Seats are allocated based on the results. Another novelty of UNEs is that applicants became free to apply to several universities and various departments at the same time, unlike the previous system under which they had only one choice.

Since the introduction of UNEs, the number of admitted students as a percentage of the total number of school-leavers has been growing. The number of students applying to universities has increased as well: currently about 60 per cent of students from the relevant age-cohort register for UNEs and over 45 per cent are admitted.

UNEs continue to be one of the most well-received reform measures, widely supported by the public as well as representatives from the full political spectrum. A number of reports and research projects show that UNEs have effectively addressed the issue of corruption (Karosanidze and 
Christensen 2005; Orkodashvili 2009). It is more difficult to assess whether or not the second goal of promoting equal chances for access has been achieved. This is due to lack of data on the social background of admitted students as well as lack of pre-UNE data. However, there are indications that the system still favours those from advantaged backgrounds, especially where funding is concerned, as elaborated in the subsequent sections.

There are legitimate concerns that the examination system results in 'teaching to the test' in the final years of secondary school. The International Institute for Education Policy, Planning and Management carried out a study which reports that the large majority of students attend private tutoring classes in their final secondary school years to better prepare for the test (Machabeli et al. 2011).

Furthermore, lack of HEI involvement in the admissions process is a serious issue. UNEs currently provide a necessary and sufficient channel to enrol in any HEI. Therefore, HEIs themselves have no authority to select students based on their own criteria and preferences. Interestingly, however, there was no opposition from HEIs against such a drastic imposition on their agency. This could have been the result of a heavy-handed approach adopted by the government in 2005 to fight corruption. However, a decade later, the time seems ripe to reconsider the admissions policies and give universities the right to decide which students they want to admit.

One side effect of the UNE is that it allowed for the division of universities by selection standards to be more standardised throughout the country. It is now possible to rank HEIs by level of selectivity with average UNE scores received for enrolled students. In her study on the effect of rural residence on university admissions, Chankseliani (2013) divides all HEIs into five categories based on mean student scores on three compulsory examinations. Such informal ranking of HEIs by average UNE scores has become popular. As the Examination Centre annually announces the highest scoring students and the HEIs in which they are enrolled, this evaluation of HEI rank and prestige is self-reinforcing.

\section{Funding}

Public expenditure on education as a share of GDP and as a share of total government spending remains among the lowest in the region. Despite the fact that overall public expenditure increased from 2004 onwards, the relative share of education has hardly changed. The share of education 
spending has varied between 2 and 3 per cent of GDP since 2000, and more recently the share of public spending on higher education has been estimated at around 1.2 per cent (Salmi and Andguladze 2012).

The introduction of standardised examinations coincided with a fundamental change in the higher education funding system. This change, in line with the government's liberal economic ideology, was carried out in two major ways. Firstly, the funding mode changed to exclusively per capita; secondly, the overall share of private (household) costs in funding higher education increased (Chakhaia 2013).

The government of Georgia has substantively changed its funding mechanisms to increase transparency and efficiency in allocating public resources. Previously, funds were allocated to HEIs based on several factors including number of students and staff, specific needs including capital repair, and negotiations and connections. This system was gradually replaced by one under which funds are allocated only to students who qualify for public funding as a result of UNE scores. The state established a ceiling for tuition fees at national universities and admitted students were awarded study grants based on UNE scores in the amount of 100 per cent, 70 per cent, 50 per cent, 30 per cent or 0 per cent of the maximum public university tuition. Those not able to secure 100 per cent funding have to cover the remaining costs themselves. Only about 30 per cent of all admitted students are currently receiving grants, and only about 5 per cent receive grants for 100 per cent. This effectively means that the overwhelming share of $\mathrm{HE}$ funding costs are generally borne by students and their families (Chakhaia 2013).

A major innovation and a step towards the economic liberalisation of the system was to include private universities in this scheme. Students who enrol in private universities are also entitled to state grants, conditional to their performance on the national exams. This way, private universities also receive state funding. Alongside improving transparency and efficiency, the system was designed to increase competitiveness among universities (both public and private), as attracting more students means receiving more funding.

A similar approach was used for funding research: direct allocations for research institutions were slowly replaced by competitive research grants based on quality criteria administered by a semi-independent agency under the Ministry of Education and Science of Georgia (MoES). Previously, research institutes (within the Academy of Science) received lump-sum funding. Such modification of the funding process for research activities additionally strengthens the research component at HEIs and supports the integration of research and instruction. 


\section{Conclusions}

The development of the Georgian higher education system during the last 25 years has closely followed changes in the political and socioeconomic life of the country. Throughout the chapter, we have emphasised the usefulness of dividing this development trajectory into two periods: from 1991 to 2004, and from 2004 to the present.

The first period was characterised by somewhat haphazard and chaotic system development, as well as relative HEI freedom and lack of concerted reform effort. Governance of higher education, in fact, reflected the general pattern of public governance in the country: rampant corruption, lax regulations and lack of vision for development. It can be argued that during the period, particularly during the first years of independence, higher education developed in a legal and regulatory void.

The changes observed in higher education before 2004 were therefore largely determined by economic factors (i.e. transition to the market economy) and related changes in labour demand. The spectacular growth of private HEIs resulted from unrestricted supply without governmental regulations as a response to the growing demand for university education. Public HEIs were perhaps a little late in recognising the market potential of admitting fee-paying students. Both public and private HEIs had the freedom to adjust their programmes in accordance with market demands. Weak or absent quality assurance mechanisms were conducive to such developments.

Radical changes to this lax approach took place with the arrival of a new government in November 2003. With overwhelming support from the electorate and a vow to increase transparency and efficiency, sweeping reforms based on market principles were introduced in all public sectors. Higher education was a flagship of this crusade against corruption and inefficiency. Quality assurance mechanisms were introduced, corruption was eradicated and competition was encouraged. However, HEIs themselves have remained passive receivers of change throughout the process, as the changes were centrally planned and implemented.

\section{Note}

1. As opposed to the previously existing system under which all student studies were subsidised from the public budget. 


\section{REFERENCES}

Bakradze, L. 2013. Strategic Development of Higher Education and Science Integration of Teaching and Research. Tbilisi: EPPM.

Chakhaia, L. 2013. Funding and Financial Management of Educational Research. Tbilisi: Education Policy, Planning and Management.

Chankseliani, M. 2013. Rural Disadvantage in Georgian Higher Education Admissions: A Mixed-Methods Study. Comparative Education Review 57: 424-456.

Darchia, I. 2013. Strategic Development of Higher Education and Science in Georgia - Quality Assurance. Tbilisi: EPPM.

Gvishiani, N., and D. Chapman. 2002. Republic of Georgia: Higher Education Sector Study. Washington, DC: The World Bank.

Karosanidze, T., and C. Christensen. 2005. A New Beginning for Georgia's University Admissions. In Stealing the future. Corruption in the classroom. Ten real life experiences. Georgia: Transparency International.

Lorentzen, J. 2000. Georgian Education Sector Study - The Higher Education System. Background paper. Washington, DC.: World Bank.

Machabeli, G., T. Bregvadze, and R. Apkhazava. 2011. Examining Private Tutoring Phenomenon in Georgia. Tbilisi: The International Institute for Education Policy, Planning and Management.

Mitra, P., and M. Selowsky. 2002. Transition, the First Ten Years: Analysis and Lessons for Eastern Europe and the Former Soviet Union. Washington, DC: World Bank.

OECD. 2011. Development in Eastern Europe and the South Caucasus: Armenia, Azerbaijan, Georgia, Republic of Moldova and Ukraine. OECD. Available from http://public.eblib.com/choice/publicfullrecord.aspx? $\mathrm{p}=746588$

Orkodashvili, M. 2009. Corruption in Higher Education: Causes, Consequences, Reforms. Online Submission.

Pachuashvili, M. 2009. The Politics of Higher Education: Governmental Policy Choices and Private Higher Education in Post-Communist Countries. Budapest: Department of Political Science, Central European University.

Perkins, G. 1998. The Georgian Education System: Issues for Reform Management. In Background Paper for the 1998 Georgia Education Sector Strategy Note. Washington, DC: Europe and Central Asia Region, Human Development Unit, World Bank.

Salmi, J., and N. Andguladze. 2012. Tertiary Education Governance and Financing in Georgia. Unpublished.

Savelyev, A.Y., V.M. Zuyev, and A.I. Galagan. 1990. Higher Education in the USSR. Bucharest: CEPES.

Sharvashidze, G. 2002. Private Higher Education in Georgia: Main Tendencies. Case Study Carried Out Under the IIEP Research Project on Structural Reforms in Higher Education: Private Higher Education. 
Sharvashidze, G. 2005. Private Higher Education in Georgia: Main Tendencies. Paris: UNESCO.

Transparency International. 2002. Transparency International Corruption Perception Index Report. Berlin: Transparency International.

World Bank. 2009. Georgia Poverty Assessment. Washington, DC: World Bank.

Lela Chakhaia is a doctoral researcher at European University Institute in Florence, Italy. She has extensive professional experience working for the Ministry of Education and Science of Georgia, UNICEF, Ilia State University, and so on. Her research interests include social stratification in post-soviet countries, inequalities in educational attainment and expansion of higher education.

Tamar Bregvadze is an Associate Professor at Ilia State University. At the same time, she is the member of the research team at Georgian National Examination Center coordinating a number of international and national educational assessments.

Open Access This chapter is distributed under the terms of the Creative Commons Attribution 4.0 International License (http://creativecommons.org/licenses/ by $/ 4.0 /$ ), which permits use, duplication, adaptation, distribution and reproduction in any medium or format, as long as you give appropriate credit to the original author(s) and the source, provide a link to the Creative Commons license and indicate if changes were made.

The images or other third party material in this chapter are included in the chapter's Creative Commons license, unless indicated otherwise in a credit line to the material. If material is not included in the chapter's Creative Commons license and your intended use is not permitted by statutory regulation or exceeds the permitted use, you will need to obtain permission directly from the copyright holder.

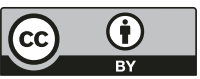

